\title{
Management of Nematodes and Soil Fertility with Sunn Hemp Cover Crop ${ }^{1}$
}

\section{K.-H. Wang and R. McSorley ${ }^{2}$ \\ Introduction}

Sunn hemp, Crotalaria juncea $\mathrm{L}$. is a rapidly growing crop that is used for fiber production in India and Pakistan. It is most popular as a green manure in many tropical and subtropical areas in the world as an organic nitrogen source. Recently, there is a growing interest in rotating sunn hemp with cotton in the southern United States and in using sunn hemp as a summer cover crop in Florida and other southeastern states. Sunn hemp suppresses weeds, slows soil erosion, and reduces root-knot nematode populations (Rotar and Joy, 1983). When plowed under at early bloom stage, nitrogen recovery is the highest. Under optimum growing conditions such as in Hawaii, 'Tropic Sun' sunn hemp can produce 134 to $147 \mathrm{lb} /$ acre of nitrogen and 3 tons/acre air-dry organic matter at 60 days of growth at $40 \mathrm{~kg}$ seed/ha (Rotar and Joy, 1983). In northern Florida, sunn hemp is usually grown in the summer and can produce 2.4 tons/acre of dry biomass and 98 to $125 \mathrm{lb}$ N/acre (Marshall, 2001). In southwestern Alabama, plants grown for 9 to 12 weeks produced 2.6 tons/acre dry-matter and $112 \mathrm{lb}$ N/acre (Reeves et al., 1996). Although in the tropics, 'Tropic Sun' grows and produces seed year-round at elevations of 0 to $900 \mathrm{ft}$, and in summer up to $1800 \mathrm{ft}$, sunn hemp does not set seed well in Florida (R. Gallaher, personal communication). Sunn hemp is usually planted in summer in Florida (Rotar and Joy, 1983), but it is suitable as a green manure crop as far north as Maryland. The greatest challenge in using sunn hemp as a cover crop in U.S. is seed availability (see section below). Detailed cultivation and other ecological information on sunn hemp can be obtained from

http://www.hort.purdue.edu/newcrop/duke_energy/ Crotalaria_juncea.html.

\section{History}

In 1958, the National Resources Conservation Service (NRCS) (formerly the Soil Conservation Service), and the University of Hawaii purchased seeds of Crotalaria from a farmer who was growing it as a cover crop on the island of Kauai. This germplasm was used to develop the sunn hemp cultivar 'Tropic Sun.' 'Tropic Sun' seed was released in 1982 by the NRCS and University of Hawaii (Rotar and Joy, 1983). The Agricultural Research Services Poisonous Plant Laboratory and the University of Hawaii determined that seeds of this

1. This document is ENY-717, one of a series of the Department of Entomology and Nematology, Florida Cooperative Extension Service, Institute of Food and Agricultural Sciences, University of Florida. Date first printed: September 2004. Please visit the EDIS Web site at http://edis.ifas.ufl.edu.

2. K. -H. Wang and R. McSorley, Department of Entomology and Nematology, Cooperative Extension Service, Institute of Food and Agricultural Sciences, University of Florida, Gainesville, FL.

The Institute of Food and Agricultural Sciences (IFAS) is an Equal Employment Opportunity - Affirmative Action Employer authorized to provide research, educational information and other services only to individuals and institutions that function without regard to race, creed, color, religion, age, disability, sex, sexual orientation, marital status, national origin, political opinions or affiliations. For information on obtaining other extension publications, contact your county Cooperative Extension Service office. Florida Cooperative Extension Service / Institute of Food and Agricultural Sciences / University of Florida / Larry R. Arrington, Interim Dean 


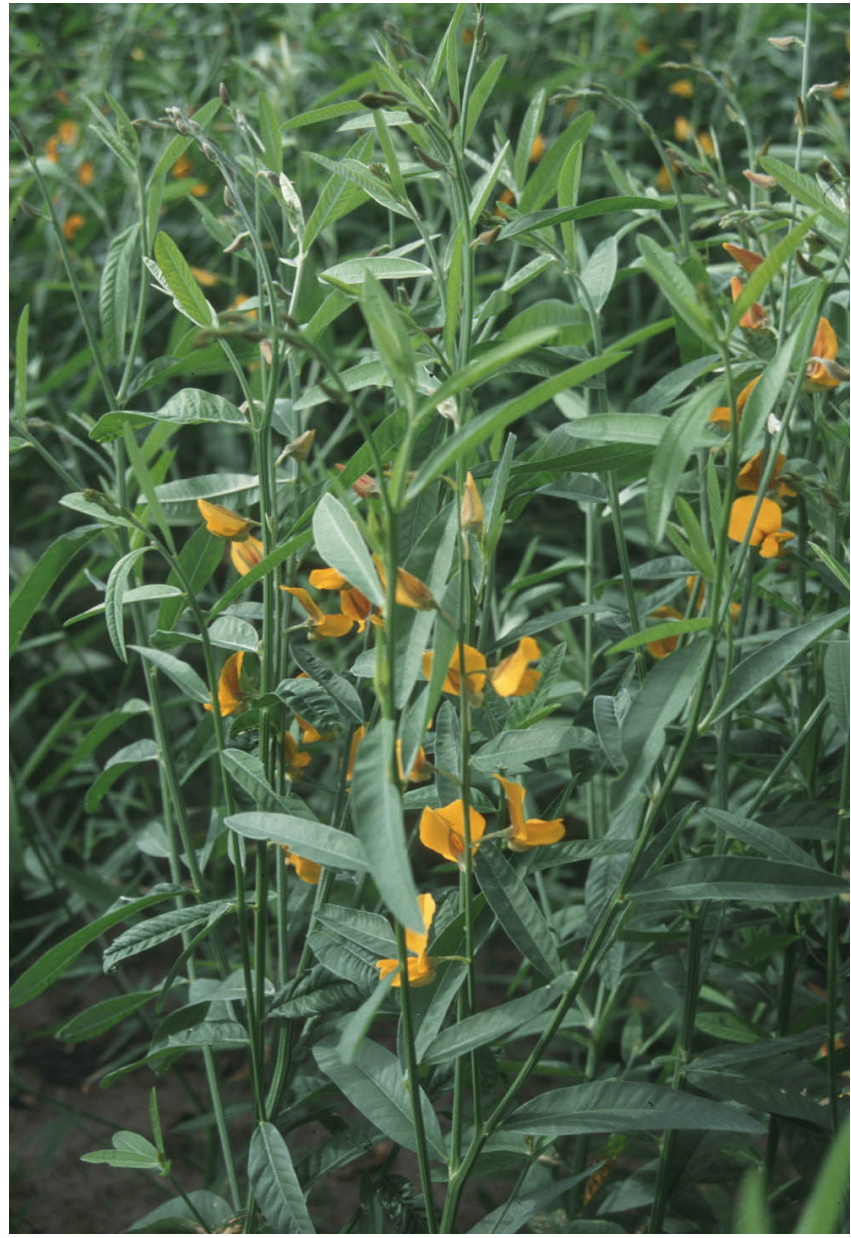

Figure 1. Crotalaria juncea at early flowering stage.

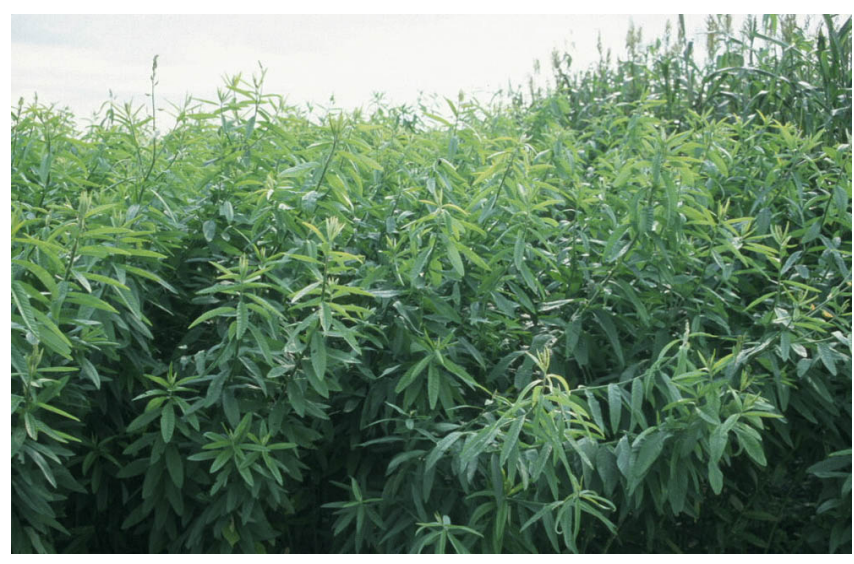

Figure 2. $C$. juncea at vegetative stage.

cultivar were not toxic to livestock, and the plant was resistant to root-knot nematodes (Rotar and Joy, 1983).

\section{Sunn Hemp as a Fertilizer}

Sunn hemp is most commonly used as a green manure, where it is grown for 2 to 3 months before cash crop planting and then incorporated into the soil at early blooming stage. Besides use as a green manure, sunn hemp can also be used as organic mulch where the cover crop is mowed and left on the soil surface. The advantage of using a leguminous cover crop as an organic mulch rather than green manure is that this practice will slow down the release of nutrients from the crop residues, and allow the nutrients to be available for the subsequent cash crops over a longer period of time. It had been demonstrated that sunn hemp can be grown as a winter cover crop in Alabama, and leaving the residues on the soil surface over the winter resulted in the release of 67 to $71 \mathrm{lb}$ N/acre (Reeves et al., 1996). Research done in south Florida suggested that when sunn hemp is used as green manure and organic mulch, it should be seeded at high rates (49-58 $\mathrm{lb} / \mathrm{acre}$ ) and the crop terminated at 10-12 weeks from the planting date (Abdul-Baki et al., 2001).

\section{Currently, the greatest challenge in using sunn} hemp as a cover crop in the U.S. is seed availability. Recent research has attempted to increase this cover crop biomass production with minimum seeding rate, and also to increase seed production. Research in south Florida concluded that cutting sunn hemp stems at $1 \mathrm{ft}$ above soil level 100 days after planting (when plants were about $5 \mathrm{ft}$ tall) and allowing the plants to grow for an additional 70 days resulted in the highest quality of green manure harvested as compared to uncut or cutting at a higher stem height. This is because cutting at $1 \mathrm{ft}$ increased leaf yield (Abdul-Baki, et al., 2001). This increased the $\mathrm{N}$ content of the biomass harvested because leaf tissues contained higher concentration of $\mathrm{N}(3.96 \%)$ than the stem tissues $(0.88 \%)$ and whole plant tissues $(2.5 \%)$ (Marshall, 2002).

Since most of the macro-nutrients in sunn hemp are found in leaves and flowers, use of sunn hemp as green manure or organic mulch would be most beneficial at the early to mid-blooming stage (Marshall, 2002). Sunn hemp is a short-day crop, which means that it will only flower in fall when day length becomes shorter in north Florida. However, sunn hemp is very susceptible to frost kill, and so opportunity for growth and biomass increase is limited by cool temperature in the fall. Therefore immediate use of sunn hemp residues is limited to supplying nutrients only to benefit winter vegetable 
crops. Therefore, another option for use of a sunn hemp cover crop is to harvest the cover crop residues, air dry, grind up the residues, and store as organic fertilizer for later use (Marshall, 2002).

While this form of application is time consuming, it offers opportunities to manipulate fertilizer application rate and timing.

Seaman et al. (2004) reported that frequent harvest of the top 18 inches of new growth by clipping sunn hemp at 16 to 32 inches height above soil line produced an organic fertilizer of $4 \% \mathrm{~N}$. This means that if 3 tons/acre of dried sunn hemp biomass is harvested, it will contain $240 \mathrm{lb}$ of $\mathrm{N}$. Therefore, this high concentration of $\mathrm{N}$ in clipped sunn hemp materials has great potential as an organic $\mathrm{N}$ fertilizer.

The whole plant sunn hemp residues harvested at early blooming stage contained $\mathrm{N}-\mathrm{P}_{2} \mathrm{O}_{5}-\mathrm{K}_{2} \mathrm{O}$ in amounts of 123-42-80 lb/acre, which gives a ratio of 3:1:2 (Marshall, 2002). Using this ratio, one can formulate a fertilizer according to the specific crop nutrient requirement. Marshall (2002) demonstrated that sunn hemp residue supplied $\mathrm{N}$ levels comparable to those derived from inorganic $\mathrm{N}$ for bush bean (Phaseolus vulgaris), lima bean (P. lunatus), okra (Abelmoschus esculentus), cucumber (Cucumis sativus), cowpea (Vigna unguiculata), sweet corn (Zea mays) and squash (Cucurbita pepo).

\section{Nematode Suppression}

Suppression of plant-parasitic nematodes by Crotalaria spp. has been known for decades. Godfrey (1928) noted that sunn hemp had few root galls from infection with root-knot nematodes (Meloidogyne spp.). Most of the plant-parasitic nematodes suppressed by Crotalaria are sedentary endoparasitic nematodes, which are nematodes that remain and feed in one place within the root system. These include root-knot, soybean cyst (Heterodera glycines) and reniform (Rotylenchulus reniformis) nematodes (Wang et al., 2002). Some migratory nematodes such as sting (Belonolaimus longicaudatus), stubby root (Paratrichodorous minor), dagger (Xiphinema americanum), and burrowing (Radopholus similis) nematodes were also suppressed by other plants in the genus Crotalaria (Wang et al., 2002). Table 1 summarizes results of studies on host status of sunn hemp and effects of using sunn hemp as a preplant cover crop or intercrop on various plant-parasitic nematodes.

\section{How Does Sunn Hemp Suppress Plant-parasitic Nematodes?}

Sunn hemp uses different modes of action to suppress plant parasitic nematodes, making it an efficient cover crop for nematode management. Sunn hemp is not only a poor host or nonhost to many plant-parasitic nematodes (Table 1), but it has been shown to produce allelopathic (toxic) compounds against several key nematode pests. Jasy and Koshy (1994) demonstrated that leaf extract of sunn hemp was lethal to burrowing nematode (Radopholus similis) at dilutions of 1:5 within 24 hours. Wang et al. (2001) also found that sunn hemp leaf leachate essentially stopped movement of the reniform nematode, $R$. reniformis.

Sunn hemp also can enhance natural enemies of plant-parasitic nematodes, such as fungi that trap nematodes or feed on their eggs (Wang et al., 2001). Besides suppressing plant-parasitic nematodes directly, sunn hemp can also manage nematode damage on crop indirectly by increasing plant tolerance against these pests. Sunn hemp amendments have been demonstrated to enhance free-living nematodes in the soil that are involved in nutrient cycling (Wang et al., 2003c), thus increasing nutrients available for plant uptake. A healthier plant will then have a higher tolerance to plant-parasitic nematode damage.

\section{Pests and Diseases}

The crop has few pest and pathogen problems. Major diseases of sunn hemp are Fusarium wilt caused by Fusarium udum var. crotalariae and anthracnose caused by Collectotrichum curvatum (Purseglove, 1974). In Brazil, the only disease reported on the crop is Ceratocystes fimbriata. (National Research Council, 1979). The three most serious insect pests for sunn hemp are larvae of the sunn hemp moth, Utetheisa pulchella; the stem borer, Laspeyresia pseudonectis; and pod borers (Purseglove, 1974). Pod borers can lower seed 
production of $C$. juncea. Sunn hemp is also a host to the stink bug, Nezara viridula (Davis, 1964) and African sorghum head bug, Eurystylus oldi (Malden and Ratnadass, 1998).

\section{Seed Availability Problems}

Shortage of seed supplies and increased seed prices are drawbacks for cover cropping of sunn hemp in U.S. Retail market value of seeds currently averages $\$ 1.81 / \mathrm{lb}$. Recommended seeding rate for cover cropping is $45-73 \mathrm{lb} / \mathrm{acre}$. This seed cost is discouraging to growers. Expanding seed production of sunn hemp in the U.S. beyond Hawaii is challenging. It is known that sunn hemp may not seed well north of $30^{\circ}$ latitude. Climate in Florida should be suitable for sunn hemp seed production. However, in Florida, sunn hemp flowers well but seed production is poor. In southern Florida, Abdul-Baki et al. (2001) proposed to enhance sunn hemp seed production by increasing stem branching through pruning at $90 \mathrm{~cm}$ height.

\section{How to Enhance Sunn Hemp Effects in Suppressing Nematode Pests?}

Although sunn hemp has good potential as a cover crop for managing several important plant-parasitic nematodes, the residual effects are short-term (a few months). While sunn hemp is a poor host to many plant-parasitic nematodes, nematode numbers can resurge to damaging levels on subsequent host crops (McSorley et al., 1994). This scenario strongly suggests that integrating the sunn hemp rotation system with other nematode management strategies is necessary. Among the possibilities for integration are crop resistance, enhanced crop tolerance, selection for fast growing crop varieties, soil solarization, and biological control.

Nematicides should be avoided in a cropping system if the objective is to enhance nematodeantagonistic microorganisms. Several studies have demonstrated the destructive effect of fumigation treatments to nematode antagonistic microorganisms. Sunn hemp could enhance activities of nematodetrapping fungi (NTF) in the rhizosphere or in soil amended with its biomass (Wang et al, 2001, 2003a), but it failed to enhance NTF populations in soils that were recently treated with the nematicide 1,3-dichloropropene (Wang et al, 2003b).

In summary, sunn hemp, besides serving as an efficient green manure, is a poor host to many important plant-parasitic nematodes, produces compounds toxic to nematodes, and is able to enhance some nematode-antagonisitc microorganisms. Therefore using sunn hemp as a cover crop could offer an alternative for managing nematodes. By integrating with other pest management strategies, the development of new sustainable cropping systems with sunn hemp is promising.

\section{References}

Abdul-Baki, A. S., H. H. Bryan, G. M. Zinati, W. Klassen, M. Codallo, N. Heckert. 2001. Biomass yield and flower production in sunn hemp - effect of cutting the main stem. Journal of Vegetable Crop Production 7: 83-104.

Fassuliotis, G., and G. P. Skucas. 1969. The effect of pyrrolizidine alkaloid ester and plants containing pyrrolizidine on Meliodogyne incognita acrita. Journal of Nematology 1: 287-288.

Godfrey, G. H. 1928. Legumes as rotation and trap crops for pineapple fields. Experiment Station of the Association of Hawaiian Pineapple Canners Bulletin 10: 3-21.

Jasy, T., and P. K. Koshy. 1994. Effect of certain leaf extracts and leaves of Glyricidia maculata, (H. B. \& K) Steud. as green manure on Radopholus similis. Indian Journal of Nematology 22: 117-121.

Malden, J. M., and A. Ratnadass. 1998. Crotalaria juncea (Fabaceae) cited for the first time as alternative host of Eurystylus oldi important pest of sorghum and ricinus (Hem., Miridae). Bulletin de la Societe Entomologique de France 103: 272.

Marshall, A. J. 2002. Sunn hemp (Crotalaria juncea L.) as an oranic amendment in crop production. M.S. Thesis, University of Florida, Gainesville, FL. 
McSorley, R., D. W. Dickson, J. A. Brito, T. E. Hewlett, and J. J. Frederick. 1994. Effects of tropical rotation crops on Meloidogyne arenaria population densities and vegetable yields in microplots. Journal of Nematology 26: 175-181.

National Research Council. 1979. Tropical legumes: resources for the future. National Academy of Science, Washington, D.C. pp. 272-278.

Purseglove, J. W. 1974. Tropical crops: Dicotylendons. Longman Group Limited, London.

Reeves, D. W., Z. Mansoer, and C. W. Wood. 1996. Suitability of sunn hemp as an alternative legume cover crop. in Proceedings of the New Technology and Conservation Tillage 96 (7): 125-130. University of Tennessee Agricultural Experiment Station, Tennessee.

Rotar, P. P., and R. J. Joy. 1983. 'Tropic Sun' sunn hemp, Crotalaria juncea L. Research Extension Series 036. College of Tropical Agriculture and Human Resources, University of Hawaii. 7 pp.

Seaman, K. A., R. N. Gallaher, and R. McSorley. 2004. Maintaining clipping heights to enhance yield and nitrogen content for sunn hemp. Soil and Crop Science Society of Florida Proceedings 63: (in press).

Wang, K.-H., Sipes, B.S., and Schmitt, D.P. 2001. Suppression of Rotylenchulus reniformis by Crotalaria juncea, Brassica napus, and Target erecta. Nematropica 31, 237-251.

Wang, K.-H., Sipes, B.S., and Schmitt, D.P. 2002. Crotalaria as a cover crop for nematode management: a review. Nematropica 32:35-57.

Wang, K.-H., Sipes, and B.S., Schmitt, D.P. 2003a. Suppression of Rotylenchulus reniformis enhanced by Crotalaria juncea amendment in pineapple field soil. Agriculture, Ecosystem and Environment 94: 197-203.

Wang, K.-H., R. McSorley, R. N. Gallaher. 2003b. Effect of Crotalaria juncea amendment on nematode communities in soil with different agricultural histories. Journal of Nematology 35: 294-301.
Wang, K.-H., R. McSorley, R. N. Gallaher.2003c. Effect of Crotalaria juncea amendment on nematode communities in soil with different agricultural histories. Journal of Nematology 35: 294-301. 
Table 1. Host status and effects of using Crotalaria juncea in crop rotation or intercropping system on plant-parasitic nematodes (From Wang et. al., 2002b).

\begin{tabular}{|c|c|c|}
\hline Nematode & Host Status & Crop Rotation or Intercropping Effect \\
\hline Meloidogyne arenaria & Poor host (McSorley, 1999) & - \\
\hline M. exigua & Resistant (Silva et al., 1990a) & - \\
\hline M. hapla & $\begin{array}{l}\text { Roots almost totally galled, but few egg masses } \\
\text { found (Martin, 1958). }\end{array}$ & - \\
\hline M. incognita race 1 & $\begin{array}{l}\text { Poor host (McSorley, 1999), poorer host than } \\
\text { cotton (Robinson and Cook, 2001) }\end{array}$ & $\begin{array}{l}\text { Suppressed numbers on cotton (Robinson } \\
\text { et al., 1997).* }\end{array}$ \\
\hline M. incognita race 3 & Resistant (Santos and Ruano, 1987) & - \\
\hline M. javanica & $\begin{array}{l}\text { Poor host (McSorley, 1999); smaller giant cells } \\
\text { (Silva et al., 1990b); no galls, no juveniles } \\
\text { (Araya and Caswell-Chen, 1994); galls visible } \\
\text { (Martin, 1958). }\end{array}$ & $\begin{array}{l}\text { Suppressed numbers on taro (Sipes and } \\
\text { Arakaki, 1997); on tobacco (Shepherd and } \\
\text { Barker, 1993); on sugarcane (Moura, 1991). }\end{array}$ \\
\hline $\begin{array}{l}\text { Pratylenchus } \\
\text { brachyurus }\end{array}$ & $\begin{array}{l}\text { Survived but failed to multiply (Charchar and } \\
\text { Huang, 1981) }\end{array}$ & - \\
\hline P. zeae & $\begin{array}{l}\text { Poorer host than sorghum but can penetrate } \\
\text { roots (Silva et al., 1989). }\end{array}$ & - \\
\hline $\begin{array}{l}\text { Rotylenchulus } \\
\text { reniformis }\end{array}$ & $\begin{array}{l}\text { Poor host (Caswell et al., 1991; Wang et al., } \\
\text { 2001; Silva et al., 1989; Robinson and Cook, } \\
\text { 2001) }\end{array}$ & $\begin{array}{l}\text { Reduced numbers on pineapple (Wang et } \\
\text { al., 2002). }\end{array}$ \\
\hline Radopholus similis & $\begin{array}{l}\text { Leaf extract at } 1: 5 \text { dilution is toxic (Jasy and } \\
\text { Koshy, 1994) }\end{array}$ & $\begin{array}{l}\text { Intercropping with banana reduced } \\
\text { nematode numbers (Charles, 1995); did not } \\
\text { suppress the nematodes when grown as } \\
\text { preplant cover crop without biomass } \\
\text { incorporation (Inomoto, 1994). }\end{array}$ \\
\hline $\begin{array}{l}\text { Helicotylenchus } \\
\text { multicinctus }\end{array}$ & ** & $\begin{array}{l}\text { Intercropping with banana reduced } \\
\text { nematode numbers (Charles, 1995). }\end{array}$ \\
\hline Hoplolaimus indicus & - & $\begin{array}{l}\text { Intercropping with banana reduced } \\
\text { nematode numbers (Charles, 1995). }\end{array}$ \\
\hline
\end{tabular}

